\title{
Der Schachfreund.
}

Lehrbuch des Schachspiels

an praktischen Beispielen.

Fưr Anfänger und Geübtere.

Herausgegeben von

Jean Dufresne, mit Beiträgen von A. Anderssen.

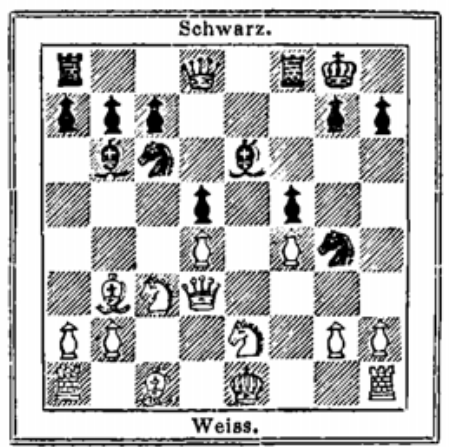

Berlin, 1862.

Verlag von Carl Heymann. 
